Leadership: Jurnal mahasiswa manajemen Pendidikan Islam ISSN (P): 2721-7108, ISSN (E): 2715-0399

DOI : http://dx.doi.org/10.32478/leadership. v2i2.812

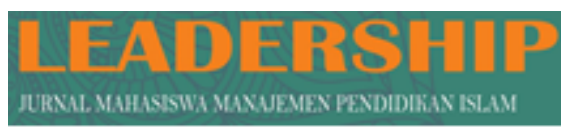

Article Type : Original Research Article

\title{
MANAJEMEN KEPEMIMPINAN DALAM PENGEMBANGKAN SKILL SANTRI (Studi Kasus Di Pondok Pesantren Mahasiswi Daruzzahra Arrifa'i Kota Malang)
}

\author{
Nury Firdausia \\ STAIMA Ma'had Aly Al-hikam Malang, Indonesia
}

Corresponding author: firdausianury@gmail.com

Copyright @ 2021 Author

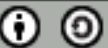

This work is licensed under a Creative Commons Attribution-ShareAlike 4.0

\section{Abstract}

Pesantren institution needs to change to positive things continuously because there is a hope for society from the output of pesantren. The development of the pesantren management is one of solution which used for increasing the quality of pesantren. The management will accompany and give an advice for the process of pesantren. Not unlike other educational institutions such as formal schools, pesantren education also requires management to develop or advance a pesantren. Management is an important thing in the management of Islamic boarding schools to continue and maintain the quality and progress of the pesantren. Pesantren whose management system is low or even bad, can result in reduced efficiency of a pesantren. Therefore, Islamic boarding schools need management, especially the leadership management of caregivers in developing the skills of their students.

Keyword: Pesantren, Management

\begin{abstract}
Abstrak
Lembaga pesantren perlu mengadakan perubahan positif secara terus-menerus seiring dengan harapan besar dari masyarakat terhadap output Pesantren. Pengembangan Manajemen Pesantren merupakan salah satu solusi yang dapat digunakan untuk meningkatkan kualitas atau mutu pesantren. Manajemen mengawal dan memberikan arahan pada proses berjalannya sebuah lembaga pesantren dapat terpantau. Tidak berbeda dengan lembaga pendidikan lain seperti sekolah formal, pendidikan pesantren juga membutuhkan manajemen untuk mengembangkan atau memajukan sebuah pesantren. Manajemen merupakan hal yang penting dalam pengelolaan pondok pesantren untuk terus menajaga kualitas dan kemajuan pesantren tersebut. Pesantren yang sistem manajemennya rendah atau bahkan tidak baik, bisa mengakibatkan mengurangnya daya guna sebuah pesantren. Karena itu Pesantren perlu manajemen khususnya manajemen kepemimpinan Pengasuh dalam penegembangan skill para santrinya.
\end{abstract}

Keyword: Pesantren, Manajemen 


\section{A. PENDAHULUAN}

Islam telah menerapkan prinsip bagaimana mengatur dan mengerjakan sesuatu secara tertib, baik dan benar. Begitu juga dalam mengatur sebuah lembaga pendidikan, pondok pesantren adalah salah satu lembaga pendidikan yang seyogyanya memiliki manajamen atau pengelolaan yang sistematis, terukur dan terstruktur untuk mencapai visi misi dan tujuan lembaga pendidikan tersebut. Kecakapan pengasuh pondok pesantren juga termasuk dalam manajemen kepemimpinan, dalam kasus tertentu manajemen kepemimpinan juga berdampak pada pengembangan skill santri pondok pesantren, karena itu penulis mengambil studi kasus manajemen kepemimpinan dalam pengembangan skill santri di Pondok Pesantren Mahasiswi Daruzzahra Arrifa'i yang nantinya dianalisis dengan teori manajemen Pendidikan dan kepemimpinan.

Pondok pesantren merupakan model Pendidikan tertua dan sampai saat ini memiliki eksistensi yang tidak kalah dengan Pendidikan umum serta memiliki kepercayaan yang di tinggi dari masyarakat sekitar. Pondok Pesantren Daruzzahra Arrifa'i adalah Pesantren Mahasiswi yang berbasis pada Tahfidz al-Quran dan Daiyah Trainer, pesantren ini juga fokus pada pengembangan kualitas santrinya dengan model pengembangan skill, sehingga manajemen kepemimpinan dalam pengembangan skill ini menjadi suatu progress yang baik kedepannya.

Pada struktur Pendidikan nasional, pesantren merupakan mata rantai yang sangat penting dalam dunia Pendidikan. Khususnya pada pondok pesantren yang berbasiskan mahasiswi. Peranan pengasuh dalam mengelola pondok pesantren juga menjadi faktor yang sangat penting dalam menjalankan visi dan misi pondok tersebut. Tidak hanya pengasuh yang berperan aktif, bantuan dari pihak lain juga menjadi salah satu faktor penting seperti pemateri dan pelatih yang ahli dalam bidang tertentu sehingga dalam kegiatan pondok dapat terlaksana dengan baik. Kemudian dorongan dan motivasi untuk santri juga perlu diberikan setiap saat agar santri tidak merasa jenuh dan bosan dengan aktivitas pondok yang monoton.

Berbicara terkait da'i atau berdakwah untuk menyebarkan agama Islam itu tidak semudah membalikkan tangan, banyak kendala yang dihadapi di lapangan sehingga daiyah diharuskan memiliki bekal untuk menghadapi persoalan tersebut. Selain problem dari luar dalam berdakwah juga membutuhkan kesiapan mental dan penguasaan materi sehingga seorang da'iyah juga betul -betul faham tentang apa yang akan disampaikan karena ini menyangkut tentang agama yang mana akan di pertanggung jawab kan di akhirat kelak.

Menjadi da'i merupakan sesuatu hal yang di anggap istimewa karena dapat menjelaskan secara detail dan rinci tentang agama. Pembelajaran dakwah harus diterapkan mulai sejak dini seperti di jenjang smp maupun sma, pada studi kasus ini pondok pesantren Daruzzahra Arrifa'i menerapkan belajar menjadi da'iyah meskipun mereka belajar di bangku perkuliahan menjadi seorang mahasiswi.

Menguasai ilmu dakwah atau berpidato merupakan skill yang sangat mahal dan banyak di cari orang karena hal tersebut tidak hanya harus menguasai pengetahuan yang luas namun harus memiliki keterampilan dalam menyampaikan pengetahuannya kepada orang lain. Problematika yang dihadapi di era sekarang ini yaitu kurangnya peminat serta kurangnya ketertarikan para generasi penerus bangsa kita ini mejadi seorang pendakwah sehingga pada kesempatan kali ini izinkan penulis untuk mengupas apa saja problematika yang terjadi pada era ini. Selain pengembangan skill da'iyah di pondok juga di kembangakan juga keterampilan 
untuk menghafal al - qur'an, karena dengan menghafal seseorang akan terus mengasah otaknya serta motorik. Banyaknya manfaat dalam menghafal menjadikan pondok ini membuat program tahfidzil qur'an

Dalam hal ini diperlukannya pengelolaaan dalam kepemimpinan untuk mengatur bagaimana teknis menghafal serta mengamalkan apa yang telah di hafal sehingga ilmu apa yang telah di pelajari itu menjadi manfaat. Memimpin suatu pondok pesantren bukanlah sesuatu yang mudah karena dibutuhkan skill serta softskill yang mumpuni terlebih lagi pondok pesantren yang berbasiskan Tahfidz dan Da'iyah Trainer yang juga merupakan mahasiswi di berbagai kampus di kota Malang, yang mana pola pikir mereka pasti sudah terbentuk dengan baik, mau tidak mau seorang pengasuh juga membutuhkan manajemen pengelolaan yang baik.

\section{B. METODE PENELITIAN}

Penelitian ini adalah penelitian kualitatif yang bersifat studi pustaka (library research) yang menggunakan buku-buku dan literature-litaratur lainnya sebagai objek yang utama. ${ }^{1}$ Jenis penelitian yang digunakan adalah kualitatif, yaitu penelitian yang menghasilkan informasi berupa catatan dan data deskriptif yang terdapat pada teks yang diteliti. ${ }^{2}$

Melalui penelitian ini, maka analisis deskriptif perlu dilakukan. Metode ini menggambarkan serta memberi penjelasan yang kritis, analitis, sistematis, objektif, serta jelas. Dasar untuk pendekatan ini yaitu pada langkah awal yang penempuhannya dengan mengumpulkan data yang diperlukan dan selanjutnya akan diklasifikasikan serta dideskripsikan.

\section{HASIL DAN DISKUSI}

\section{Model Pengembangan skill yang dipimpin oleh Pengasuh Pondok Pesantren Daruzzahra Arrifa'i}

Lembaga pesantren perlu mengadakan perubahan positif secara terus-menerus seiring dengan harapan besar dari masyarakat terhadap output Pesantren. Pengembangan Manajemen Pesantren merupakan salah satu solusi yang dapat digunakan untuk meningkatkan kualitas atau mutu pesantren. Manajemen mengawal dan memberikan arahan pada proses berjalannya sebuah lembaga pesantren dapat terpantau. Tidak berbeda dengan lembaga pendidikan lain seperti sekolah formal, pendidikan pesantren juga membutuhkan manajemen untuk mengembangkan atau memajukan sebuah pesantren. ${ }^{3}$ Manajemen merupakan hal yang penting dalam pengelolaan pondok pesantren untuk terus menajaga kualitas dan kemajuan pesantren tersebut. Pesantren yang sistem manajemennya rendah atau bahkan tidak baik, bisa mengakibatkan mengurangnya daya guna sebuah pesantren.

Seorang pemimpin adalah seorang yang bergerak lebih awal, berjalan di depan, mengambil langkah pertama, berbuat paling dulu, mempelopori suatu tindakan, mengarahkan pikiran/pendapat/tindakan orang lain, membimbing, menuntun, menggerakkan orang lain melalui pengaruhnya. Pemimpin juga sering disebut dengan berbagai nama: penghulu,

\footnotetext{
${ }^{1}$ S. Hadi. Metodologi Research. Jilid 3. (Yogyakarta: Andi Offset, 1995), hlm. 3

${ }^{2}$ Bagoes Mantra Ida, Demografi Umum. (Yogyakarta: Pustaka Pelajar, 2008), hlm. 30

${ }^{3}$ Halim dkk, Manajemen Pesantren, (Yogyakarta:PT Lkis Pelangi Aksara, 2005) hal:70-71
} 
pemuka, pelopor, pengarah, pembimbing, penuntun, penggerak, dan khalifah (dalam bahasa Arab).

Kepemimpinan adalah proses mempengaruhi aktifitas individu atau kelompok untuk mencapai tujuan-tujuan tertentu dalam situasi yang telah ditetapkan. Dalam mempengaruhi aktifitas individu, pemimpin menggunakan kekuasaan, kewenangan, pengaruh, sifat dan karakteristik; dan tujuannya adalah meningkatkan produktifitas dan moral kelompok. Kekuasaan adalah kemampuan seseorang menarik orang lain untuk melakukan sesuatu. Kekuasaan bersumber dari legitimasi, hak, dan paksaan.

Pesantren atau lebih dikenal dengan istilah pondok pesantren dapat diartikan sebagai tempat atau komplek para santri untuk belajar atau mengaji ilmu pengetahuan agama kepada kiai atau guru ngaji, biasanya komplek itu berbentuk asrama atau kamar-kamar kecil dengan bangunan apa adanya yang menunjukkan kesederhanaannya.

Pondok pesantren adalah suatu lembaga pendidikan tradisional Islam untuk mempelajari, memahami, mendalami, menghayati, dan mengamalkan ajaran Islam dengan menekankan pentingnya moral keagamaan sebagai pedoman perilaku sehari-hari. ${ }^{4}$

Dari berbagai pengertian di atas, maka dapat dipahami bahwa pesantren adalah lembaga pendidikan Islam tradisional yang mempelajari ilmu agama (tafaqquh fi al-dîn) dengan penekanan pada pembentukan moral santri agar bisa mengamalkannya dengan bimbingan kiai dan menjadikan kitab kuning sebagai sumber primer serta masjid sebagai pusat kegiatan.

Dalam konteks ini Pondok Pesantren Daruzzahra Arrifa'i memiliki basis pesantren mahasiswa yang mana santri tidak sama dengan santri yang ada di pondok - pondok salaf atau pondok pada umumnya, keleluasan dalam menggapai akses pun dibebaskan karena itu merupakan kebutuhan mereka sebagai mahasiswi.

Apabila kebijakan dari pengasuh pondok menggunakan sistem manajemen seperti pondok salaf maka kebebasan serta mobilitas mahasiswi (santriwati) juga terbatas dan akan berdampak pada kegiatan proses belajar yang ada di kampusnya. Pemberian kebebasan itu tidak serta merta dibebaskan semaunya namun juga tetap ada regulasi yang membatasinya yang proposional seperti pada penggunaan Handphone, Penggunaan Sepeda Motor dan jam keluar masuk area pondok. Kebijakan pengasuh dalam memimpin pondok pesantren juga tidak lepas dari kebijakan yang di keluarkan oleh Universitas yang dimana para santriwati itu menempuh studi di kampusnya masing - masing. Karena hal itu juga sering kontras pada kegiatan yang diselenggarakan oleh pondok, mau tidak mau pondok harus memberi izin apabila santriwati tersebut memiliki kegiatan yang ada di kampus mereka.

Pesantren Daruzzahra Arrifa'i ini juga memberikan izin dan selalu mempertimbangkan dalam masalah perizinan tersebut, bukan karena apa namun ini bertujuan agar visi dan misi serta harapan pondok pesantren pada masing - masing santriwati dapat terwujud karena pondok juga memiliki amanah untuk menjaga dan mengembangkan bakat serta keterampilan yang dimiliki seorang satriwati tersebut.

Model kepemimpinan pengasuh dalam praktik di lapangan, pengasuh mempunyai gaya memimpin, diantaranya: ${ }^{5}$

${ }^{4}$ Haedari, Amin, dkk, Masa Depan Pesantren Dalam Tantangan Modernitas dan Kompleksitas global, Cet, 1; Jakarta: IRD Press, 2004. Hlm.32 
a. Karismatik, pola memimpin di mana pemimpin menyuntikan gelora semangat untuk rekannya kemudian penuh semangat untuk kemajuan. Dalam kepemimpinannya, pengasuh sangat kental dengan gaya ini, semua bawahannya memiliki kepatuhan amat besar kepadanya.

b. Paternalistik, maksud dari corak kepemimpinannya ialah mempunyai ciri khas kebapakaan, sangat perhatian kepada bawahanya dan terus di arahkan untuk memperoleh perkembangan yang semakin baik.

c. Autokratik, ialah keputusan mengenai suatu kebijakan berada di satu arah dan bersifat mutlak. Kekuasan sepenuhnya milik pengasuh yang menguasai seluruh jajarannya.

d. Populistik Kesolidaritasan setiap anggota dibangun oleh pemimpin yang sangat menjungjung tinggi moralitas yang ada di masyarakat awam.

e. Demokratik, corak dari gaya ini adalah mempunyai tujuan kemanusian dan terus melakukan arahan yang nyata untuk semua divisinya. Masukan yang membangun sangat dihargai, kemampuan individual terus mendapat perhatian dan menghargai kinerja dari jajarannya.

Pengasuhnya Pesantren Daruzzahra Arrifa'i memiliki lima karakter pemimpin pesantren yang telah disebutkan, dengan gayanya yang kharismatik, paternalistik, autokratik, populistik dan demokratik, pengasuh dari pondok pesantren ini selalu menyemangati para santrinya khususnya semangat menjadi da'iyah dan menghafal Al-Qur'an, karena dari keduanya itu juga butuh motivasi, apresiasi dan dorongan dari seseorang yang dianggap spesial yaitu pengasuh pondok nya sendiri hal itu merupakan hal yang sangat dibanggakan. Berikut model pengembangan skill da'iyah (da'iyah trainer) dan Tahfidzil qur'an. di Pondok Pesantren Daruzzahra Arrifa'i:

1) Da'iyah Trainer

Berdakwah bukan hanya sebatas orasi atau berpidato di depan umum, namun berdakwah juga memiliki tanggung jawab yang lebih besar yakni apa yang di sampaikan akan dipertanggung jawabkan di akhirat nanti,berdakwah juga butuh keterampilan yang tinggi dan tidak dapat dipelajari dalam kurun waktu yang singkat kecuali ada bakat dalam diri orang tersebut mimiliki jiwa atau mental pemberani dalam berdakwah. Dalam manajemen kepemimpinan yang di terapkan oleh pengasuh di Pondok Pesantren Daruzzahra Arrifa'i ini menerapkan semua santriwati wajib mengikuti program da'iyah traner ini, karena ini merupakan lifeskills yang sangat bermanfaat apabila mereka para santriwati pulang ke daerahnya masing-masing.

Didalam aturan, tata tertib dan teknis dari pelaksanaan program da'iyah trainer ini juga telah dilakukan dengan baik dan benar. Setiap santriwati selalu dibimbing dan di perhatikan dengan penuh sampai mereka benar - benar mampu berdakwah dan terjun di Masyarakat. Tidak hanya latihan di dalam pondok atau berdakwah ke teman - temannya namun di dalam program ini mereka juga di ajarkan untuk berdakwah dan langsung terjun ke masyarakat, bukan hanya teori atau praktik di dalam pondok saja yang mereka dapatkan namun praktik di lapangan mereka juga dapat.

Model pengembangan ini merupakan model pembelajaran atau pengajaran yang sangat baik karena dapat membentuk mental para santriwati secara tidak langsung maupun langsung. Di sini, pesantren diharap mampu mengembangkan dan mempengaruhi tradisi

\footnotetext{
${ }^{5}$ Siti Muriah, Metodologi Dakwah Kontemporer, Yogjakarta: Mitra Pustaka, 2000. Hlm.34
} 
Islam di tengah pengaruh dahsyat globalisasi yang berupaya menyeragamkan budaya melalui produk-produk teknologi.

\section{2) Tahfidzil Qur'an}

Pondok Pesantren Daruzzahra Arrifa'i ini memiliki program unggulan yang kedua yaitu tahfidzil qur'an, yang mana program ini banyak di minati banyak dari mahasiswi yang ingin meneruskan hafalannya karena belum selesai di pondok sebelumnya karena terkendala lanjut ke jenjang perkuliahan sehingga mengharuskan keluar dari pondok sebelumnya dan ada juga yang ingin atau termotivasi untuk menghafal mulai dari awal, maka dari itu pengasuh pondok membuat program tersebut.

Melihat padat nya kesibukan para mahasiswi didalam mengatur atau membuat strategi agar para santriwati ini disisi lain kuliah jalan dan menghafal juga berjalan pada kepemimpinannya pengasuh memberikan motivasi serta cara jitu untuk menghafal al-qur'an seperti yang penulis kutip Menurut Yahya Al-Ghausani, ada lima kiat percepatan menghafal Al-Qur'an sebagai berikut: ${ }^{6}$

a) Tahyiah Nafsiah Persiapkan diri kita sejak malam hari, maksudnya hindari begadang di malam hari karen dengan seringnya begadang akan membuat ngantuk di waktu subuh. Hendaknya sebelum tidur juga rencanakan esok hari akan menghafal bagian surat yang sama.

b) Taskhin (melakukan penghangatan) Layaknya sebuah kendaraan, sebelum dipakai mesin harus dipanaskan terlebih dahulu. Begitupun dengan otak kita, setelah semalaman diistirahatkan maka perlu penghangatan dengan cara luangkan waktu beberapa menit untuk mengulang hafalan lama, ataupun membaca ayat yang akan dihafalkan waktu itu.

c) Tarkiz (konsentrasi).

d) Tikrar (mengulang-ngulang).

e) Tarabuth (mengaitkan redaksional dengan makna) Langkah yang bisa ditempuh ialah membaca terjemahan dari ayat yang sedang kita hafalkan, ini akan membantu kecepatan dalam menghafal.

\section{Problematika yang dihadapi oleh Pengasuh}

Program dibentuk dan dibuat sesuai dengan basic atau visi misi dari tujuan awal pondok pesantren di bangun. Bukan hanya untuk sebatas pengisi dari kegiatan pondok tapi ini seharusnya dapat di manfaatkan sebaik mungkin terlebih lagi program yang dibuat oleh Pondok Pesantren Daruzzahra Arrifa'i ini. Namun dalam merealisasikan program tersebut tidak semulus yang dibayangkan pastinya terkendala dan adanya problematika yang dihadapi pengasuh, beberapa solusi yang dilakukan pun masih muncul problematika tersebut. Karena tujuan utama dakwah adalah untuk mengajak mad'u (obyek dakwah) kejalan yang benar yang diridhai Allah. Maka materi dakwah harus bersumber dari sumber pokok ajaran Islam, yakni Al-Qur'an dan Al-Hadist. Namun, karena luasnya materi dari kedua sumber tersebut, maka perlu adanya pembatasan yang disesuaikan dengan kondisi mad'u.

${ }^{6}$ Kholis, Nur. "Pengembangan Sistem Pendidikan Dan Pengajaran Pesantren." Skripsi, Fakultas Tarbiyah IAIN Sunan Ampel 1990. 


\section{a. Problematika Da'iyah trainer}

Materi dakwah adalah isi pesan atau materi yang disampaikan da'i kepada mad'u. Sumber utamanya adalah Al-Qur'an dan Al-Hadis. Pada dasarnya materi dakwah Islam tergantung pada tujuan dakwah yang hendak dicapai. Namun, secara global dapatlah dikatakan bahwa materi dakwah dapat diklasifikasikan menjadi tiga hal pokok, yaitu:

1) Masalah Keimanan (Aqidah) Aqidah artinya ketetapan yang tidak ada keraguan pada orang yang mengambil keputusan. Sedang pengertian aqidah dalam agama maksudnya adalah berkaitan dengan keyakinan bukan perbuatan. Seperti aqidah dengan adanya Allah dan diutusnya pada Rasul. Bentuk jamak dari aqidah adalah aqaid.

2) Masalah Keislaman (Syari'ah) Materi dakwah yang bersifat syari'ah ini sangat luas dan mengikat seluruh umat Islam. Syariah dalam Islam adalah berhubungan erat dengan amal lahir (nyata) dalam rangka mentaati semua peraturan atau hukum Allah guna mengatur hubungan antara manusia dengan Tuhannya dan mengatur pergaulan hidup antara sesama manusia. Disamping mengandung dan mencakup kemaslahatan soisal dan moral, materi dakwah juga untuk memberikan gambaran dan kejadian hujjah atau dalil - dalil agar tidak terperosok dalam kejelekan, karena tujuan dalam dakwah dan yang diinginkan adalah dalam hal kebaikan.

3) Masalah budi pekerti (Akhlakul Karimah)

Akhlak mulia yaitu suatu sikap yang baik sesuai ajaran agama Islam. Seseorang yang memiliki akhlakul karimah maka akan disenangi oleh sesama manusia, bahkan tidak hanya itu jika seseorang berperilaku sesuai ajaran agama Islam maka sudah pasti baik dimata Allah dan kelak nanti akan masuk dalam surga bersama nabi Muhammad saw.

Aqidah mengikat kalbu (hati) manusia dan menguasai batinnya. Akidah yang nantinya membentuk moral manusia dan menguasai batin dalam hal kebaikan maupun kejelekan. Oleh karena itu, yang dijadikan materi dakwah Rasulullah yakni akidah dan keimanan terlebih dahulu. Dengan iman kita akan kukuh dan tangguh serta pengorbanan yang akan selalu menyertai setiap langkah dalam hidup kita. Masalah akhlak dalam aktivitas dakwah (sebagai materi dakwah) merupakan pelengkap saja, yakni untuk melengkapi keimanan dan keislaman seseorang. Meskipun akhlak ini sebagai pelengkap, bukan berarti masalah akhlak kurang penting di bandingkan dengan masalah keimanan dan keislaman, akan tetapi akhlak adalah sebagai penyempurna keimanan dan keislaman.

\section{b. Problematika Menghafal Al - Qur'an Bagi Seorang Mahasiswi}

Menghafal merupakan kegiatan yang sangat menyenangkan seharusnya itu yang ditanamkan dalam mindset penghafal al - qur'an, namun setelah itu tertanam akan muncul lagi yaitu bagaimana caranya agar menanamkan mindset mengulang - ngulang hafalan itu lebih menyenangkan karena mengulang hafalan itu merupakan kegiatan yang paling bagus daripada menambah tapi tidak mengulang sama sekali. Problematika menghafal bagi seorang mahasiswi atau santriwati yang ada di Pondok Pesantren Mahasiswi Daruzzahra Arrifa'i yaitu:

1) Malas melakukan simaan (saling menyimak hafalan)

Melakukan simaan merupakan salah satu metode yang paling ampuh bisa sesama teman, senior, atau kepada guru yang ada di pondok tersebut. Hafalan akan cepat dan mudah hilang jika tidak melakukan ke istiqamahan dan mengulang hafalan al-Qur'an. 
Pada dasarnya konsep dalam memelihar dan menjaga hafalan yaitu membutuhkan sebuah keistiqamahan agar hafalan tidak mudah hilang.

2) Tidak mengulang hafalan secara rutin

Tidak istikamah mengulang-ulang dan memperdengarkan hafalan al-Qur'annya. Dengan pandai mengatur waktu, penghafal Al-Qur'an akan terbantu dalam memelihara hafalannya. Dengan mengatur waktu, ia akan selalu mengulang hafalan yang secara continou. Oleh karena itu, biasakan lah untuk tidak melewatkan waktu tanpa melakukan hal - hala yang bermanfaat. Dengan demikian ketidak konsistenan dalam mengulang hafalan juga akan mempercepat hilangnya hafalan.

3) Terlalu berambisi menambah banyak hafalan baru

Salah satu faktor cepat lupa dan hilang karena tergesa - gesa dalam menghafal dan ingin haflannya cepat selesai dalam waktu yang singkat. Sebab, apabila hafalan sebelumnya belum lancar, usaha hafalan yang sudah di hafal menjadi sia - sia.

Di Pondok Pesantren Daruzzahra Arrifa'i ini problematika utamanya yaitu masih ada beberapa santri belum percaya diri dan pesimis ketika berbicara di depan umum, sehingga pangasuh terus mencari solusi dan terus memotivasi para santriwati nya agar terus mau belajar dan berlatih untuk berdakwah. Tidak lupa apresiasi dari pengasuh merupakan sesuatu yang spesial bagi santriwati sehingga mereka bersemangat untuk terus belajar dan belajar.

\section{Solusi serta Kebijakan yang dilakukan oleh Pengasuh Pondok dalam Menyelesaikan Problematika}

Solusi serta kebijakan pengasuh Pondok Pesantren Mahasiswi Daruzzahra Arrifa'i untuk problematika pada program Da'iyah Trainer yaitu :

a. Menanamkan konsep bahwa menjadi da'i itu menyenangkan

Pada tahap awal semua pengajar pasti telah menanamkan konsep da'l itu menyenangkan namun harus di tananamkan secara terus menerus agar mereka tidak bosan dan Lelah dalam proses belajar.

b. Mendatangkan motivator dari luar

Mendapatkan ilmu itu banyak jalannya salah satunya yaitu mendatangkan guru yang memiliki pengalaman yang lebih banyak. Di Pondok Pesantren Daruzzahra Arrifa'i ini sering mendatangkan motivator yang berpengalaman.

c. Selalu memberi apresiasi

Apresiasi merupakan bentuk ungkapan dan hadiah untuk memberikan semangat, bukan hanya semangat saja namun santriwati akan lebih giat untuk terampil dan percaya diri saat tampil di depan umum.

Solusi serta kebijakan pengasuh Pondok Pesantren Mahasiswi Daruzzahra Arrifa'i untuk problematika pada program Tahfidzil Qur'an yaitu :

1) Memberikan Penghargaan

Pemberian penghargaan kepada santriwati yang istiqomah untuk megulang-ulang bacaan al-qur'anya bisa menjadi solusi untuk meningkatkan semangat para santriwati 
sehingga teman-temannya juga ikut bersaing namun tetap bertujuan pada Allah swt (Fastabiqul khairat).

2) Memberikan macam-macam strategi menghafal

Fitrah manusia memang cepat bosan, maka dari itu pengasuh Pondok Pesantren Daruzzahra Arifa'i ini memberikan berbagai strategi menghafal agar para santriwati tidak bosan Ketika menggunakan strategi atau trik menghafal al-Qur'an dengan berbagai metode.

\section{PENUTUP}

\section{Kesimpulan}

Manajemen pengelolaan pondok pesantren merupakan kewajiban yang harus dimiliki oleh setiap pondok pesantren. Manajemen mutu yang baik dapat mendukung pengembangan potensi atau skill santri sehingga dapat diandalkan saat terjun dan berdakwah di masyarakat.

Pondok Pesantren Daruzzahra Arrifai telah menjadi pelopor dalam pengembangan skill santri dengan manajemen kepemimpinan yang aktif dan inovatif, dengan pengembangan daiyah trainer dan tahfidz al-Qur'an. Ada beberapa problem yang harus dihadapi dan dicari solusinya, namuan hal itu tidak menghambat kegiatan yang telah berjalan dengan baik. Sikap terbuka dan karismatik dari pengasuh juga menjadi faktor pendukung bagi manajemen pesantren yang baik.

\section{Saran}

Pesantren sebagai lembaga pendidikan memiliki sejarah yang cukup panjang dalam membangun pendidikan khususnya bangsa Indonesia, sehingga diperlukan upaya untuk terus diadakan pengkajian dan penelitian sehingga kita mendapatkan informasi yang jelas.

Setiap organisasi, termasuk pendidikan pondok pesantren memiliki aktivitas-aktivitas pekerjaan tertentu dalam rangka mencapai tujuan organisasi. Salah satu aktivitas tersebut adalah manajemen. Dengan pengetahuan manajemen, pengelola pondok pesantren bisa mengangkat dan menerapkan prinsip-prinsip dasar serta ilmu yang ada di dalam Al-Qur'an dan Hadis ke dalam lembaganya tersebut. Maka hanya dengan manajemen lembaga pendidikan pesantren diharapkan dapat berkembang sesuai harapan, karena itu manajemen merupakan sebuah niscaya bagi lembaga pendidikan Islam atau pesantren untuk mengembangkan lembaganya ke arah yang lebih baik. 
Leadership: Jurnal mahasiswa manajemen pendidikan Islam

ISSN (P): 2721-7108, ISSN (E): 2715-0399

Vol. 02 No. 02 bulan Juni 2021

\section{Daftar Pustaka}

Ali, Mukti, Beberapa Persoalan Dewasa Ini, Jakarta: Rajawali Press, 1987

Haedari, Amin, dkk, Masa Depan Pesantren Dalam Tantangan Modernitas dan Kompleksitas global, Cet, 1; Jakarta: IRD Press, 2004

Halim dkk, Manajemen Pesantren, (Yogyakarta:PT Lkis Pelangi Aksara, 2005) hal:70-71

Kholis, Nur. "Pengembangan Sistem Pendidikan Dan Pengajaran Pesantren." Skripsi, Fakultas Tarbiyah IAIN Sunan Ampel 1990.

Siti Muriah, Metodologi Dakwah Kontemporer, (Yogjakarta: Mitra Pustaka, 2000)

Masyhud, Sulthon dkk., Manajemen Pondok Pesantren, (Jakarta : Diva Pustaka, 2003) 